Int J Antisep Disinfect Steril 2016;1(1):13-8 doi: 10.14744 /ijads.2016.76486

\title{
Dare to change
}

\author{
Wim RENDERS \\ World Federation for Hospital Sterilization Sciences, Brugge, Belgium
}

\begin{abstract}
SUMMARY
As departing president of the World Forum for Hospital Sterile Supply (WFHSS), now the World Federation for Hospital Sterilization Sciences, I would like to offer my view on the world of sterilization. I would first like to underline the important role national sterilization associations have played and continue to play. Established in the 1970s to the 1990s, they have been a major catalyst for the evolution of sterilization. International contact between them became more and more frequent and it was soon apparent that cooperation between associations could lead to better national practice. That was the basis for the creation of the European Forum for Hospital Sterile Supply (EFHSS), from which WFHSS originated. What certainly must not be overlooked is that Central Sterile Supply Departments (CSSD) are responsible for the most critical step, namely the conversion of theory into practice. In order to do this well, an evidence-based definition of "state of the art" is essential and this definition should be globally applicable. To grow with a rapidly changing hospital environment, sterilization professionals must be willing to change. In the future, investments will have to be made in uncompromising quality, a high degree of flexibility and excellent service, attention to members of staff, and especially patient care. This requires an open mind and courage - the courage to change!
\end{abstract}

Keywords: Central Sterile Supply Departments; change; future of sterilization; WFHSS.

$\mathrm{F}_{\mathrm{F}}$ 1999 until 2014, I was president of the World Forum for Hospital Sterile Supply (WFHSS), now known as the World Federation for Hospital Sterilization Sciences. At the 2014 congress in Prague, my mandate ended. Therefore, you can consider this article my retrospective, my philosophical view on the world of sterilization.

For me - after all, every individual is the center of his own universe - I can safely say that these 15 years have been, on a human level anyway, very enriching. The presidency has given me the opportunity to explore the parameters of my personality, to scan my own limits and to get the utmost, and hopefully the best, out of myself. Based on this experience, I recommend that everyone think about what the motto of the Gruuthuuse lineage, a medieval noble family from Bruges, Belgium, might mean to him or her ${ }^{[1]}$ After 500 years, their motto: "Plus est en vous," or, "More is in you," is still valid.

It invites us to leave our comfort zone. It invites us to not evade the challenges that we encounter in our life, but rather to face them and address them positively. This way, one grows as a person. This way, we give more sense

How to cite: Renders W. Dare to change. Int J Antisep Disinfect Steril 2016;1(1):13-8.

Correspondence: Wim Renders, PhD, MD. Collaert Mansionstraat 168000 Brugge, Belgium.

e-mail:w.y.m.renders@gmail.com

Submitted: April 05, 2016 Accepted: April 26, 2016 Available online date: May 10, 2016 
and depth to our existence. Only in this way can we penetrate to the core of our being. We have to demolish the psychological and other walls that we have gradually built within ourselves. From time to time, we come to the conclusion that we do not succeed from behind those walls, and we must accept that. Confucius already knew, 2500 years ago, that "Our greatest victory is not that we never fail, but that we, whenever we stumble, rise again," ${ }^{2]}$ Indeed what is worse than to admit that we are limited? The answer to this question is that we did not even try to push our boundaries. This leaves us behind, frustrated, and dissatisfied with ourselves.

WFHSS gave me the opportunity to undertake this journey. I can only recommend that you go on the same internal expedition. I can assure you that it will be an exciting adventure. In fact, the most important thing is taking on the challenges, both professional and private, that we come across in our life. The rest will follow by itself, automatically.

Along the way, encounters with colleagues have given my trip a particular added value. They are special as individuals, but most of all, they are ordinary people. They are fellow workers in sterilization departments and hospitals, heads of associations and representatives of industry. They all have a passion and enthusiasm to advance sterilization, scientifically and/or organizationally, in common. Their authenticity, their drive, is something touching for me. They have been a reason to go on and not to give up, because they counted on me, and I could not let them down. Thanks to them I was not alone in the ongoing struggle for better sterilization. But even more importantly, it is mainly thanks to such people that the field of sterilization has changed. I would like to take this opportunity to engage all of you in this. After all, all of you who are interested in sterilization are also part of my story. I not only want to thank you for your support, but even more so for your commitment, through sterilization, to a better life for our patients, and therefore for your commitment to a better world. Your efforts, your example of cooperation, may be a positive signal that gives hope to others. In light of the current tragedies that increasingly grip the world - I am referring here to the increasing number of armed conflicts resulting in unprecedented refugee flows, and the inability to solve those conflicts in a nonviolent way - the belief that you can secure a positive future is a matter of survival. Your dedication can have the same effect as the flapping of the wings of a butterfly and can bring change, because if everyone is sweeping his or her own doorstep, the whole street will be clean.

It is only given to exceptional people to change the world alone. As a group, it is much easier. As a group, we are strong enough to make progress that is both universal and lasting. For me, that is the explanation for the creation of national sterilization associations.

Without the binding framework of an association, sterilization departments worked and sometimes still work in a kind of vacuole, each by itself, each for itself. Since quality is dependent on the individual, this naturally leads to wide variation in the output of departments. This situation was, and is, as it still exists in various countries, unacceptable. It is unacceptable for patients, for sterilization departments, for hospitals, and for ministries of health. The establishment of national sterilization associations has reversed this. Indeed, the big jump forward in many departments only happened when they started collaborating within the framework of a national society.

- A collective approach is the fastest route to our goal: to put a device that meets a high quality standard at the disposal of the care provider and the patient.

- A collective approach is a condition sine qua non for individual departmental progress.

- Or, "Unity is strength."

A national association provides the ideal channel for the transfer of knowledge to the Central Sterile Supply Departments (CSSD) by organizing study days and congresses, and setting up training courses, and thus creating a higher level of awareness and expertise. An association can also function as a partner with whom the authorities can discuss relevant matters. As a result, it is possible to draw up guidelines and codes of conduct, and even more importantly, their application can be made compulsory. This is, of course, a catalyst for change and the progress of CSSD. An association is the lynchpin for nationwide good sterilization practice. That's why I've always tried to support the activities of local associations by attending congresses.

Most European societies were created in the 1970s and 1980s. These associations explored their own backyard without really having structural contact with one another. For a small association, like that of Belgium, where little expertise was available, no research was performed; this was not an ideal situation because we had to rely mainly on commercial information from industry. We soon realized the need for international cooperation to objectify the available information. We realized the need for international contacts in order to improve national practice.

That was the basis for the creation of the European Forum for Hospital Sterile Supply (EFHSS) in 1999, an organization of national European societies. But soon 
it became apparent that sterilization does not stop at the borders of the old continent.

Other continents were also making serious efforts to improve the quality of sterilization departments, and in the meantime, the Comite Europeen de Normalisation (CEN) and the International Standards Organisation (ISO) started collaborating very closely, with the aim of arriving at a worldwide harmonization of norms. ${ }^{[3]}$

Globalization had become an irrepressible force in the field of sterilization as well. The EFHSS board recognized this and it adopted the name of the forum during the board meeting held in Lillehammer, Norway: World Forum for Hospital Sterile Supply (WFHSS).

The primary role of a national or international association is to introduce change to sterilization departments by giving information and by converting information into knowledge. Jan Hoborn ${ }^{[4]}$ once said: "Knowledge is the best medical device." The departments are and will remain responsible for the most critical step in the process, namely the conversion of theory into practice. Indeed, if we do not succeed in bringing about change on the shop floor, the existence both of a national society and of the WFHSS is useless. Bruce Lee also underlined the importance of this step, saying: "Knowing is not enough, we must apply. Willing is not enough, we must do."[5]

My first advice to sterilization departments, therefore, is the following: Work together within the framework of the national sterilization association and together with the authorities on constant improvement and upgrading of the practice. It should be ensured that the information and guidelines distributed are the same for the entire country. This will, in the end, lead to a univocal practice. It is, for me, an absolute necessity for an efficient organization and more standardization, as well as the safe operation of all departments.

That there is an urgent need to define evidence-based practice in sterilization, the "state of the art," is exemplified in a statement made by Peter Hooper. He told me once that he was surprised that "although he had already visited a great many sterilization departments, he had never seen a department that is identical to another. They are all different."

Despite the fact that we draw on the same sources, namely directives, norms, guidelines, recommendations and more or less standardized training, it seems that the texts are interpreted differently and thus put into practice differently. Sometimes sterilization seems to be "A most individual expression of a most individual emotion." ${ }^{6]}$ Of course local factors, such as access roads, available space, and resources play an important role. Nevertheless, the question remains, should we not be searching for consensus about what an ideal department and an ideal way of working might be, and evolve in that direction?

Standardization at the department level has led to improved quality and has reduced costs. ${ }^{[7]}$ If we can do the same at a higher echelon and achieve standardization between departments, this could lead to a uniform and better national and international practice. In the margins of this, it remains an important task for associations and for ministries of health to ensure that the quest for the ideal sterilization department is not limited to a few leading hospitals with exemplary performance. Elsewhere, too, the patient has the basic right to be treated with a medical device of high quality, and the hospital has the same duty.

My second piece of advice is addressed to national associations for sterilization: Integrate and commit yourselves more on the international stage. This is too often not the case. Only in this way will you be able, together with members of WFHSS, to decide the direction sterilization will take. We have to engage in a dialogue in which all parties involved are equal partners. It is a reactive model that can only work, and will only last, if it is reciprocal. But when that is the case, sterilization can make quick, real progress everywhere.

Whether we like it or not, globalization is a fact that must be taken into account. Nowadays everything is interconnected. It is not possible to turn back time. Looking back does not help us either. It only makes us doubt. We must dare to look ahead and prepare for the future today.

An anecdote I recently read in a newspaper confirms this vision. It goes as follows: An engineer visited a site in a developing country where a canal was being built. He saw, to his astonishment, instead of excavators, hundreds of people working with shovels and wheelbarrows. When he asked why they were doing so, he was told that the intention was to give work to as many people as possible. He replied, why then didn't they work with spoons and buckets? This would surely create even more jobs. The conclusion of the article was that we have no other choice but to go with the times, to make optimal use of the current opportunities, and develop them further. In this way, we avoid awakening one day in an environment in which we are no longer competitive, let alone one with which we are compatible.

Sterilization professionals have to be open to change. But when visiting sterilization departments, I sometimes get the impression that we still often work with shovels and wheelbarrows, and perhaps even with spoons and buckets. Producing sterile surgical dressings ourselves, 
the manual cleaning of instruments, the use of linen as packaging material, and other processes and equipment that are not approved cannot be seen as truly innovative activities. In the field of sterilization, change is too often postponed for fear that we will be held responsible for what might go wrong. This reflects a culture of conservatism, petty economy and fear. To leave everything as it was before is "good." Sterilization then trudges cautiously along in a tunnel without vision and toward nowhere. We have to take off the blinders that prevent us from seeing how to work better. The status quo is no longer an option. Sterilization has to focus on change management.

Progress must be made on the basis of evidence, knowledge, and experience, or on a fundamental attitude like that described by Immanuel Kant, an $18^{\text {th }}$ century German philosopher, as "Sapere aude," or "dare to know."[8] In other words, progress must be made using the courage to listen to your own mind. I would like to add another dimension here: We also must have the courage to then implement our knowledge and expertise. The field of sterilization needs this because it has trouble letting go of traditions and habitual routines, and with making the final step to a becoming a contemporary department. Two more examples and questions: During my visits to departments, I often record that not all instruments are treated in the CSSD. The belief and confidence in one's own knowledge and skills must surely be enough by now for the CSSD to also adequately treat, for example, delicate ophthalmological instruments. And is it really necessary to build in a control of the control of the control? Once again, we must be prepared to take up our responsibilities. Choosing security should suffice. To overemphasize security is not what is required. It is time to rediscover the essence of sterilization.

I agree that innovation and change are current buzzwords that should, or must, be used to solve the problems of our contemporary society, especially our economic problems. Growth can be created. Growth provides more income for governments who have become dependent on it.

For companies, innovation is the quest for new and better products, more turnover and efficiency, and lower costs. It is also a necessary element in the fierce struggle for the survival of the company.

For a hospital, this is less often the case, as its finances are usually guaranteed by the government. This should not prevent it from using these public financial resources carefully, however, as they are becoming more and more scarce. In this, albeit special biotope, innovation is necessary in order to continue to realize the primary, social mission of the hospital, which is to provide up-to-date care to each patient within a changing framework of reference. The hospital of the future will have general practitioners and external specialists. It will be a hub in a network. The service a hospital provides will no longer stop at the exit. Today there are already pilot projects that consist of a quick discharge followed by continuous follow-up of the patient at his home via mobile devices and cloud solutions. ${ }^{[9]}$ This provides better results because patients run less risk of catching a hospital-acquired infection and can recover in their own, trusted environment.

Innovation is necessary for sterilization in order to continue to develop in an ever-changing environment. Change should have become a natural habitat for our department because during recent decades sterilization has undergone a permanent and fast evolution. It moved away from being an appendage to the operating room to an independent CSSD. It moved away from being an open area to a department that is strictly divided into different zones. It moved from being mainly manual work toward automated instrument and device reprocessing. It moved from unrestricted and uncontrolled reuse of medical devices meant for single use to responsible reuse or to a total ban on reuse. It moved from the use of chemical and biological indicators toward physical validation of sterilization processes. It moved from a quality check at the end of the sterilization process toward monitoring each step of decontamination. It moved from using untrained staff to having highly qualified members of staff. In other words, the CSSD developed from a department concentrating on the sterilization process itself to a department with the holistic approach of decontamination.

Within the general framework of Medical Devices Directive (MDD) 93/42/EEC, European and ISO norms have consolidated the first wave of change by imposing minimal norms on sterilizers for medical purposes and on the sterilization of medical devices, among other things. ${ }^{[10]}$ Later, information related to quality systems was added. This was an attempt to get control over variability in the output of the CSSD, which was often considered too high, and in order to safeguard quality on a constant basis. Quality systems were introduced in the industry after the conclusion was reached that it was not only cheaper, but also much more efficient not to check the quality of the finished product at the end of the process, but to come to a better result through command and control of the constituent processes. This concept is perfectly suited to and applicable to sterilization, since the quality of the end product is no longer visible at the end of the process. Any lack of quality can only be dem- 
onstrated when it is, in actual fact, already too late. For example, when the packaging is opened in the operating theatre, or the flaw becomes apparent after the medical device is used.

The parallels that can be drawn between sterilization and a company provide indirect proof that decontamination too, is, in essence, an industrial process, the outcome of which can be perfectly predicted if the essential requirements of process control are met. Or, as Axel Kramer recently formulated it, "Validated reprocessing is a fully controllable risk." ${ }^{\text {[11] }}$ To create the conditions to make this possible is the essential task of the CSSD. Reprocessing then becomes measurable, and hence, an objective, rational process. Industrialization should not be restricted to sterilization but should also apply to other aspects of care in general. To illustrate the necessity of this, I quote Dr. Marcus Froehling, who said,"The industrialization of care is the only way to increase the human touch of care." In addition to attention to change, industrialization also includes professionalism. The professionalism of hospital staff has to create the necessary space for a human, empathic approach to each patient. As a result, the patient can receive the attention and warmth he is in need of while experiencing traumatic circumstances in a structured way. The CSSD can play an important facilitating role in this process by providing the correct medical device to the provider of care and to the patient in a timely fashion. The ongoing flexibility of the CSSD team will be critical in bringing this about.

In the near future, the adaptability of the CSSD will be further tested. Experts predict that as a result of automation and robotics, by $2030,30 \%$ of today's jobs will disappear. ${ }^{[12]}$ The CSSD should prepare for these developments now. This is happening in a number of departments where innovation is heartily embraced. The automatic tracing of an instrument set with radio-frequency identification (RFID) is already possible today. ${ }^{[13]}$ Tracing at the instrument level with data matrix codes is being added more and more. On the basis of this coding, the CSSD of the University Hospital of Geneva, Switzerland, is testing a robot that can compose sets. At the last WFHSS congress in Prague, Pia Hilsberg and her Danish colleagues gave a presentation called "The use of robotics and automation to achieve a better work environment and efficiency." They discussed possibilities for the CSSD, including the use of a robot for the automatic handling of instrument containers, the packing of case carts, and the use of case cart trolleys that can be steam sterilized.

Bear in mind that some caution is called for in the process of decision-making and implementation: Inno- vation should not be implemented for innovation's sake. Innovation has to be directed at improvement, change, and progress. It has to be supported by scientific analysis and by motivated personnel.

I just pointed out that the CSSD provides a facilitating service in the hospital. This does not mean that its contribution can be minimized; this does not mean that our department is not important. On the contrary, the CSSD is an important partner in the total care of the patient. But we should not forget that we ourselves decide whether or not we are taken seriously. We can only be as important as the service we provide and the commitment we demonstrate. Therefore, our product should be of the highest possible quality. We can and must be big in something small; we should be $100 \%$ committed to this task. The greater our conviction to do this, the more important the CSSD will be, not in, but for, the hospital.

This requires constant alertness and a lot of empathy for the patient. The latter is not always easy, as we never get the stimulating emotional feedback of direct patient contact. Our motivation and the dedication of the staff members in our departments has to come from the realization of the importance of our service within the framework of the total care provided in the hospital and the recognition of that by management. To the extent that the members of staff of sterilization departments feel valued, they will also perform better, and their identification with a high quality end product will be higher. Their sense of self-esteem and self-respect reflects on the end product and the department, and vice versa. The extent to which the CSSD is given the recognition it deserves is directly related to the quality of that end product.

The challenge for sterilization departments is thus to create a working environment in which our members of staff love to do their jobs, where they have the opportunity to develop themselves and where they can realize the objectives of the sterilization department. This should be our contribution to the wellbeing of the patients, our brick in the wall of a better world.

It is clear that in the future, sterilization will have to put its money on uncompromising quality, high flexibility, and excellent service; on attention to its members of staff; and especially on care for the patient. This requires an open mind and courage - the courage to change!

Conflict of interest: None declared.

Peer-review: Externally peer-reviewed.

Authorship contributions: Concept - Design - Supervision - Resource - Materials - Data collection - Literature search - Writing: W.R. 


\section{References}

1. de Vries A. Flanders: A Cultural History. London: Oxford University Press; 2007.

2. Burgan M. Confucius Chinese philosopher and teacher. Mankato: Compass Point Books; 2009.

3. Malcorps G, Quintana-Soria I. The Vienna Agreement $\mathrm{CEN}$ as an International Partner (PDF). CEN StandarDays (Day 2 -Session 5). CEN, 2007.

4. Hoborn J. Humans as dispersers of microorganisms: Dispersion Pattern and Prevention. Sweden: University of Göteborg; 1981.

5. Lee B. Striking thoughts. Tokyo: Tuttle Publishing; 2000.

6. Knuvelder G. Handboek tot de geschiedenis der Nederlandse letterkunde van de aanvang tot heden, Volume 4. Malmberg: L.C.G., 1953. p. 20-30.

7. Weekers F. Outsourcing the CSSD of an academic hospital: Opportunity identification and financial analysis. Master Thesis in Business Administration. Vlerick Leuven Ghent Management School, Leuven-Belgium, 2006.

8. Guyer P, Wood A (editors.) The Cambridge Edition of the
Works of Immanuel Kant, Cambridge: Cambridge University Press; 1992.

9. it2it. De 5 belangrijkste ICT-trends in de zorg. Available at: http://www.it2it.nl/it-blog/5-belangrijkste-ict-trends-zorg (Accession date: 15/06/2015).

10. Council Directive 93/42/EEC of 14 June 1993 concerning medical devices. Official Journal L 169, 12/07/1993 P. 0001 - 0043. Available at: http://eur-lex.europa.eu/legal-content/ EN/TXT/?uri=OJ:L:1993:169:TOC.

11. Assadian O, Kramer A, Meyer G. Infection control and quality management in dental medicine and maxillofacial surgery. GMS Krankenhhyg Interdiszip 2012;7:Doc16.

12. Elkins K. Experts predict robots will take over $30 \%$ of our jobs by 2025 - and white-collar jobs aren't immune. Available at: http://www.businessinsider.com/experts-predict-thatone-third-of-jobs-will-be-replaced-by-robots-2015-5 (Accession date: 01/05/2015).

13. Swedberg C. Nutrace, Belintra Market RFID-based Surgical-Tool Tracking Solution in the U.S. Available at: http:// www.rfidjournal.com/articles/view?13416 (Accession date: 25/08/2015).

\section{Değișime cesaret \\ Wim RENDERS}

Bu yazıda, World Forum for Hospital Sterile Supply (WFHSS) eski başkanı olarak, sterilizasyon dünyası hakkındaki görüşlerimi paylaşmak istiyorum. Öncelikle ulusal sterilizasyon derneklerinin ne kadar önemli bir rol oynadığının ve oynamakta olduğunun altını çizmek isterim. Bu dernekler geçen yüzyılın 70-80 ve 90'1 yıllarında kurulmuş ve sterilizasyonun evrimi için önemli bir katalizör olmuşlardır. Uluslararası temaslar da giderek artmıştır. Dernekler arasındaki işbirliğinin daha iyi ulusal uygulamalara yol açtı̆̆ı hızla anlaşılmıştır. Bu durum daha sonradan World Federation for Hospital Sterilization Sciences’a dönüșen EFHSS'nin (European Forum for Hospital Sterile Supply) kurulması için temel olmuştur. Kesinlikle göz ardı edilmemesi gereken nokta Merkezi Sterilizasyon Ünitelerinin steril malzeme hazırlama sürecindeki en kritik adım olan teorinin pratiğe dönüştürülmesinden sorumlu olmalarıdır. Bunun en iyi şekilde yapılabilmesi için en yüksek düzeyde ve teknolojide kanıta dayalı uygulama esastır. Bu uygulamalar küresel boyutta uygulanabilir olmalıdır. Hızla değişen hastane ortamı içinde, sterilizasyon da değişime istekli olmalıdır. Gelecekteki sterilizasyon üniteleri yatırımını tartışmasız kalite, yüksek esneklik, mükemmel servis ve hasta bakımındaki personelin dikkati üzerine yapmak zorundadır. $\mathrm{Bu}$, açık bir görüş ve değişim için cesaret gerektirir!

Anahtar sözcükler: Merkezi sterilizasyon ünitesi; değişim; sterilizasyonun geleceği; WFHSS.

Int J Antisep Disinfect Steril 2016;1(1):13-8 doi: 10.14744/ijads.2016.76486 